\title{
Forced Degradation Study and Development of a Stability-Indicating Method for Amoxicillin Capsules According to ANVISA Guidelines
}

\author{
Margareth B. C. Gallo, ${ }^{\oplus *, a}$ Diogo D. do Nascimento, ${ }^{b}$ Nelson M. Nunes, ${ }^{b}$ Flávia F. M. de Sousa, ${ }^{b}$ \\ Janine Boniatti, ${ }^{\circledR b}$ José L. N. de Aguiar, ${ }^{c}$ Juliana J. S. Medeiros, ${ }^{\circ b}$ Alessandra L. Esteves, ${ }^{b}$

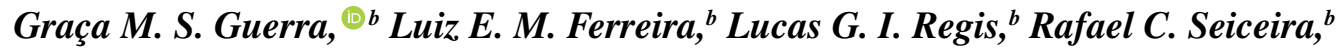 \\ Fabiana M. S. U. Moncorvo ${ }^{b}$ and Marcelo H. C. Chaves ${ }^{\circledR b}$
}

\author{
${ }^{a}$ Departamento de Saúde e Ambiente, Fundação Oswaldo Cruz (Fiocruz Ceará), 61760-000 Eusébio-CE, Brazil \\ ${ }^{b}$ Instituto de Tecnologia em Fármacos (Farmanguinhos), Fiocruz, 21040-900 Rio de Janeiro-RJ, Brazil \\ 'Instituto Nacional de Controle de Qualidade em Saúde (INCQS), Fiocruz, 21040-900 Rio de Janeiro-RJ, Brazil
}

\begin{abstract}
This study aimed to develop a reliable stability-indicating method (SIM) for amoxicillin $500 \mathrm{mg}$ capsules (DP-drug product). A literature review addressing amoxicillin (AMX; DS-drug substance) forced degradation studies and the existing SIMs was conducted to verify the most significant outcomes. Subsequently, the forced degradation of DP and DS was carried out following the Brazilian Health Surveillance Agency (ANVISA) guidelines, including thermal degradation (dry and wet heat), acidic and alkaline hydrolyses, hydrogen peroxide oxidation, reaction with copper, and photodegradation. Both DS and DP were more susceptible to $0.015 \mathrm{M} \mathrm{NaOH}$, resulting in approximately 50\% degradation. AMX DS and DP were not significantly photodegraded, but some degradation products (PDegs) showed susceptibility to light exposure. Thermodegraded samples showing $\geq 10 \%$ degradation exhibited modified profiles in thermogravimetric (TG) and differential scanning calorimetric (DSC) analyses. The X-ray powder diffraction patterns (XRPD) of DS samples exposed to dry and wet heat displayed complete amorphization of AMX, attesting to the occurrence of physical degradation concomitantly with chemical degradation, which can alter the drug's bioavailability. In contrast, the thermodegraded DP samples exhibited intact AMX crystals interspersed with the amorphous form, perhaps partly protected by the excipient. The validated SIM was able to detect and quantify about 80 PDegs.
\end{abstract}

Keywords: thermogravimetry, differential scanning calorimetry, X-ray powder diffraction, method validation, stress testing

\section{Introduction}

Amoxicillin (AMX) is an aminopenicillin antibiotic used worldwide in clinical chemotherapy that contains a highly strained $\beta$-lactam amide bond with pronounced susceptibility to several nucleophiles, acidic and alkaline reagents, metal ions, oxidizing agents, and even solvents such as water and alcohols. Concerns about AMX stability and patient safety prompted researchers to investigate AMX degradation products (PDegs) and methods capable of detecting and quantifying them, a subject that was extensively reviewed by Deshpande et $a l .{ }^{1}$ and de Marco et al. ${ }^{2}$ Initially, microbiological assays were used to determine the strength of AMX, but they had the inconvenience of not being accurate or not being able to monitor low levels of PDegs

*e-mail: margareth.gallo@gmail.com and impurities. ${ }^{3}$ High-performance liquid chromatography has emerged as an efficient method to determine AMX and its synthetic impurities, $p$-hydroxyphenylglycine ( $p$-HPG; related substance I; RS I) and 6-aminopenicillanic acid (RS A), and hydrolysis PDegs (amoxicillin penicilloic/penilloic acid epimers: RS D1/D2 and RS E1/E2, respectively) in biological fluids and dosage forms. ${ }^{4,5}$ Breakthroughs in analytical techniques have provided the means to improve the resolution, detection and characterization of AMX PDegs (Table S1, Supplementary Information (SI) section). ${ }^{6-10}$ Meanwhile, several norms on stability study and impurity control have been established by international health surveillance agencies for both DS and DP, requiring a comparison between these rules to harmonize the approach with which studies of forced degradation of drugs and development of stability-indicating methods (SIMs) should be performed. ${ }^{11}$ Even so, countless results of AMX 
degradation studies published in the literature lack details that allow its reproducibility or were not performed considering all the recommended reactions, as mentioned in Table 1, raising numerous doubts about which procedure should be followed.

Currently, only a few pharmacopoeias, e.g., British Pharmacopoeia $^{19}$ and Japanese Pharmacopoeia, ${ }^{20}$ have methods for assaying AMX and its related substances (RS) in capsules, but only the limit for individual impurities has been established. In this context, our research group started the development of a formulation for generic amoxicillin $500 \mathrm{mg}$ capsules using amoxicillin trihydrate produced by sustainable enzymatic synthesis. ${ }^{21}$

This work describes the forced degradation study of AMX DS and DP and the development and validation of a SIM, in line with the guidelines of the Brazilian Health Surveillance Agency (ANVISA), capable of detecting and quantifying about 80 PDegs. Moreover, thermogravimetric (TG), differential scanning calorimetric (DSC) and X-ray powder diffraction patterns (XRPD) analyses of the degraded samples were carried out in order to better understand the impact of AMX degradation on drug product (DP).

\section{Experimental}

\section{Chemical reagents}

Amoxicillin trihydrate, batch No. 1611503389 (assay: 99.2\% AMX; $0.06 \%$ RS A; $0.02 \%$ RS I; $0.02 \%$ RS D1; $0.09 \%$ RS D2; $0.01 \%$ RS E2; $0.17 \%$ RS J; 0.01\% RS G; $0.06 \%$ unknown impurities; $0.46 \%$ total impurities), was purchased from Aurobindo Pharma (Hyderabad, India). Amoxicillin $500 \mathrm{mg}$ capsules, batches No. 1502EX018-2 (submitted to stability study) and No. 1609EX116 (submitted to forced degradation studies and method validation), was manufactured by Farmanguinhos (Rio de Janeiro, Brazil). Analytical reference standards and reagents are listed in SI section, "Chemical reagents" sub-section.

\section{SIM development}

A Lachrom Elite high performance liquid chromatography (HPLC) system (Merck, Darmstadt, Germany) with a photodiode array detector was used to develop and validate the SIM according to the data in Table S2 (SI section).

\section{SIM validation}

The optimized HPLC method was validated according to ANVISA guidelines. ${ }^{22,23}$ The maximum reported limit
(MRL) for each RS from amoxicillin $500 \mathrm{mg}$ capsules was $1 \%$, according to the British Pharmacopoeia, ${ }^{19}$ and the Japanese Pharmacopoeia. ${ }^{20}$ Statistical analyses were performed according to Bazílio et al. ${ }^{24}$ The concentration levels, corresponding to anhydrous AMX, used to determine linearity in SIM and assay method ranged from the limit of quantitation to $120 \%$ of the $\operatorname{MRL}(0.5,1.0,2.0,3.0,4.0$, 5.0 and $\left.6.0 \mu \mathrm{g} \mathrm{mL}^{-1}\right)$ and from 80 to $120 \%$ (400, 450, 500, 550 and $600 \mu \mathrm{g} \mathrm{mL}^{-1}$ ) working concentration, respectively.

\section{X-ray powder diffraction analysis}

XRPD patterns were obtained using a X-ray diffractometer (model D8-Advance, Bruker, Karlsruhe, Germany) operated at $40 \mathrm{kV}$ and $40 \mathrm{~mA}$, using $\mathrm{Cu} \mathrm{K \alpha}$ radiation $\left(\lambda \mathrm{K} \alpha_{1}=1.54060 \AA ; \lambda \mathrm{K} \alpha_{2}=1.54438 \AA\right)$. Each sample was scanned from 3 to $50^{\circ}(2 \theta)$ at $0.2^{\circ}$ per second, which is the allowable tolerance on diffraction angle to establish identity. Crystallographic data for amoxicillin trihydrate were found in the Cambridge Structural Database. $^{25}$

\section{Differential scanning calorimetry and thermogravimetry}

DSC graphics were recorded on a calorimeter (model 822/700 DS, Mettler Toledo, Ohio, USA) under a dynamic nitrogen atmosphere at a flow rate of $80 \mathrm{~mL} \mathrm{~min}^{-1}$, scan range of $25-200{ }^{\circ} \mathrm{C}$, and heating rate of $10 \mathrm{~K} \mathrm{~min}^{-1}$. Samples weighing 3.0 to $7.0 \mathrm{mg}$ were placed in $40-100 \mu \mathrm{L}$ aluminum crucibles, which were subsequently sealed with aluminum lids and drilled with a pin at the time of the experiments. The equipment was calibrated with indium and zinc (not less than $99.99 \%$ ) for temperature and enthalpy.

Simultaneous TG was performed in a TG analyzer (model 851/LF1100, Mettler Toledo, Ohio, USA) under a dynamic nitrogen atmosphere at a flow rate of $50 \mathrm{~mL} \mathrm{~min}^{-1}$, scan range of $25-200{ }^{\circ} \mathrm{C}$, and heating rate of $10{ }^{\circ} \mathrm{C} \mathrm{min}{ }^{-1}$. Samples weighing 23.5 to $25.0 \mathrm{mg}$ were placed in covered $150 \mu \mathrm{L}$ aluminum crucibles. The module was calibrated with aluminum and indium (not less than 99.99\%) for temperature. All samples were analyzed in duplicate.

\section{Stress testing}

Amoxicillin trihydrate, amoxicillin $500 \mathrm{mg}$ capsules, and the respective placebo (magnesium stearate) were subjected to forced degradation reactions in accordance with ANVISA guidelines. ${ }^{26,27}$ The reactions were carried out using amounts corresponding to $1.25 \mathrm{mg} \mathrm{mL}^{-1}$ of anhydrous AMX in diluent 2 (0.01 $\mathrm{M} \mathrm{KH}_{2} \mathrm{PO}_{4}$ buffer $\mathrm{pH} 5 /$ 


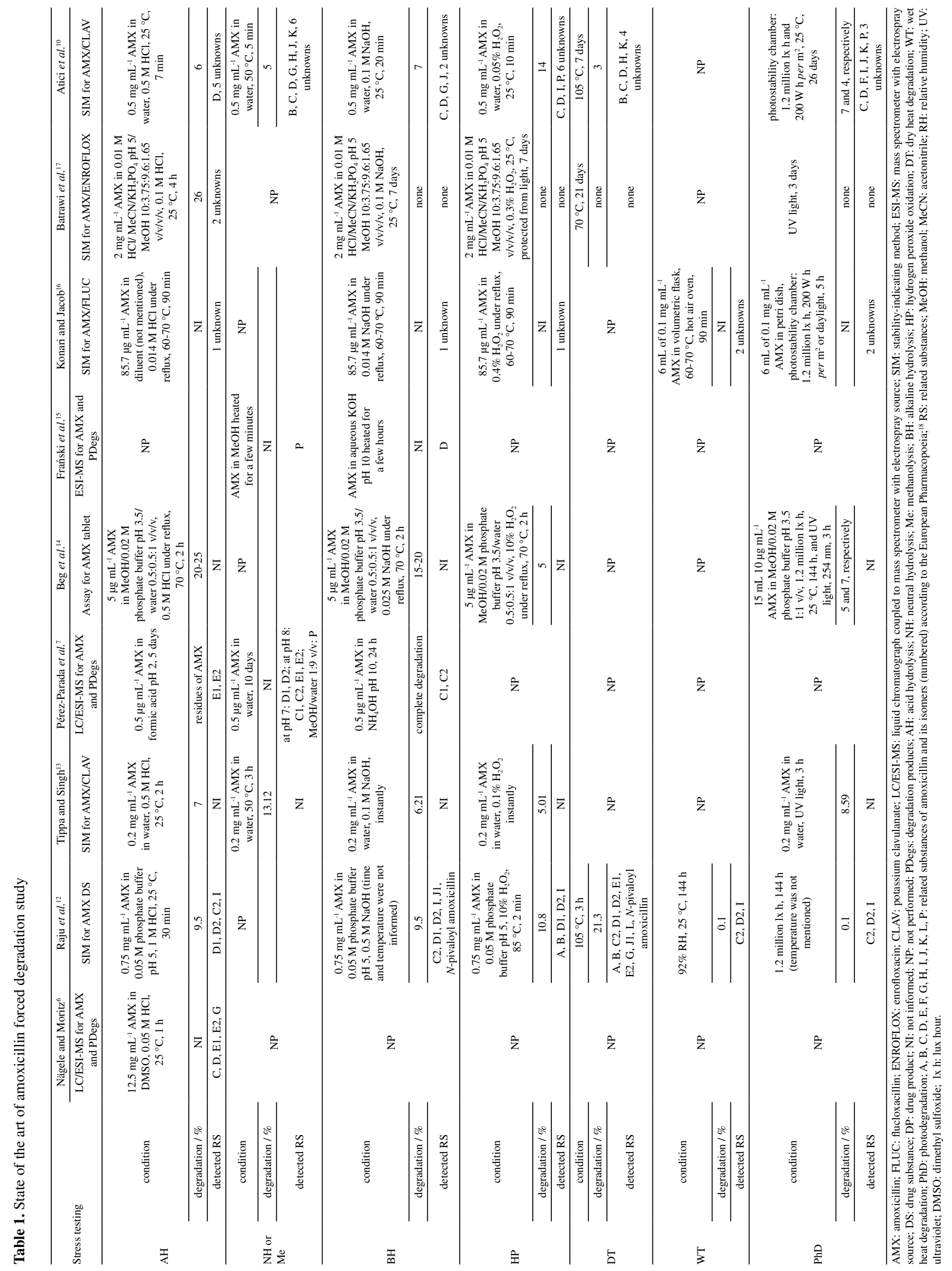


methanol 8:2 v/v) or as a thin layer of powder inside glass flasks as follows: thermodegradation in dry hot air oven at $105^{\circ} \mathrm{C}$ for $3 \mathrm{~h}$; thermodegradation in pre-saturated hot air oven with steam at $105{ }^{\circ} \mathrm{C}$ for $3 \mathrm{~h}$; photodegradation under 1.2 million-lux hours and 200 watts $\mathrm{h}$ per $\mathrm{m}^{2}$ at $25^{\circ} \mathrm{C}$ for 17 days, in a photostability chamber in which an actinometric chemical system validated using $2 \%$ quinine monohydrochloride dihydrate guaranteed exposure to light, as the difference in absorbance was $\geq 0.5 \mathrm{AU}$; acid hydrolysis in $0.375 \mathrm{M} \mathrm{HCl}$ at $25^{\circ} \mathrm{C}$ for $30 \mathrm{~min}$; alkaline hydrolysis in $0.015 \mathrm{M} \mathrm{NaOH}$ at $25^{\circ} \mathrm{C}$ for $15 \mathrm{~min}$; oxidative degradation in $1.5 \% \mathrm{H}_{2} \mathrm{O}_{2}$ at $25^{\circ} \mathrm{C}$ for $30 \mathrm{~min}$; reaction with $0.001 \mathrm{M}$ copper(II) acetate solution in water $\mathrm{pH} 3$ at $25^{\circ} \mathrm{C}$, in the absence of light, for $30 \mathrm{~min}$. Acidic and alkaline hydrolyses were neutralized with $\mathrm{NaOH}$ and $\mathrm{HCl}$ solutions, respectively. 0.1 M ethylenediaminetetraacetic acid (EDTA) was used to quench $\mathrm{Cu}^{\mathrm{II}}$-catalyzed degradation. Each sample was diluted to approximately $0.5 \mathrm{mg} \mathrm{mL}^{-1} \mathrm{AMX}$ and injected in duplicate, except for the peroxide degradation samples, which were injected only once immediately after the end of the time allotted for the reaction, as it was not quenched, as well as blank (diluent) and control (reaction medium). The chromatogram of each degraded sample (DS, DP, and placebo) was compared with the chromatograms of the blank, a non-degraded sample (reference) and the control. Peaks that occurred only in degraded samples and/ or that appeared in a greater proportion than in the reference sample were considered PDegs.

Stability studies were conducted under a long-term condition $\left(30{ }^{\circ} \mathrm{C}, 75 \%\right.$ relative humidity, 24 months), and samples were analyzed according to the SIM reported herein.

\section{Results and Discussion}

\section{SIM development}

Several methods have been described in the literature or pharmacopoeias for assaying AMX and its PDegs in the drug substances and formulated products (Tables 1, 2 and S2). Most of these methods are based on liquid chromatography coupled with an ultraviolet detector, using C18 columns and gradient elution employing phosphate or acetate buffers, $\mathrm{pH}$ 2-6, methanol, acetonitrile or a mixture as mobile phases. As our laboratory was already using the United States Pharmacopoeia method (method 1; SI section, Table S2) to assay AMX DS impurities, it seemed practical to continue using it for DP. However, when a system suitability solution containing AMX and some PDegs (SI section, "Stability-indicating method (SIM) development" sub-section) was injected, despite the very good parameters observed in the chromatogram, the method proved inadequate for the analysis of RSs because many peaks were observed in the first 3 min, including RS I, D1, D2, A, and AMX (Figure 1a). Therefore, any other degradation product formed could overlap the RS peaks whose retention times dropped in the first few minutes of running. The SIM used by the manufacturer to assay AMX DS impurities (method 2, Table S2, SI section) showed a very good resolution across all peaks (Figure 1b), but a prohibited duration of $60 \mathrm{~min}$ for an analytic method used in process control. Method 3 was based on method 2, but lasted $20 \mathrm{~min}$ less (Table S2, SI section). However, the high concentration of buffer damaged the column after 90 injections, preventing validation from being completed. Method 4, using ammonium acetate buffer, was very effective and could be validated as a liquid chromatography-mass spectrometry method (Table S2, SI section), but was not robust when transferred to the production area laboratory, exhibiting baseline oscillation for each gradient change, especially around the RS J retention time. This problem could be solved by increasing the buffer concentration to $0.01 \mathrm{M}$ and extending the run time by using $75 \%$ mobile phase A for an additional five minutes. This alternative was tried with phosphate buffer instead of acetate buffer, giving method 5 (Figure 1c; Table S2, SI section), which exhibited good baseline stability using a lower buffer concentration and had a 15 min shorter run time than method 2. The monitoring wavelength was $210 \mathrm{~nm}$, based on the maximum absorptions exhibited by the components of the system suitability solution 1 (SI section, "Stability-indicating method (SIM) development" sub-section). Degradation reactions were analyzed using method 5, and no PDegs were detected at retention times $>35 \mathrm{~min}$, therefore the method duration was reduced to $40 \mathrm{~min}$ and the validated SIM (method 5 optimized) was described in Table 2.

\section{Forced degradation profile}

When the results of AMX forced degradation were collected from the literature and analyzed, they seemed somewhat controversial regarding the percentage of degradation and the products yielded. Knowing the influence of some reagents and solvents on AMX and its related substances, ${ }^{7,28-31}$ we decided to test some diluents during the degradation study. First, AMX was dissolved in $0.05 \mathrm{M} \mathrm{KH}_{2} \mathrm{PO}_{4}$ buffer $\mathrm{pH} 5$ (named Dil1), following the manufacturer's and the US Pharmacopeia methods (methods 1 and 2, respectively, Table S2, SI section). ${ }^{12,32}$ The degradation reactions were carried out under various conditions to achieve degradation rates between 10 and $30 \%$, as suggested by the regulatory agency ${ }^{27}$ (Table 3 , 
Table 2. Assay and stability-indicating method developed and validated for AMX $500 \mathrm{mg}$ capsules

\begin{tabular}{|c|c|c|c|c|c|c|c|c|c|c|}
\hline \multirow[b]{2}{*}{ Method } & \multirow[b]{2}{*}{ Mobile phase } & \multicolumn{2}{|c|}{ Gradient } & \multirow[b]{2}{*}{ Column } & \multirow[b]{2}{*}{ 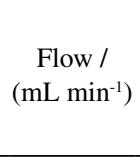 } & \multirow[b]{2}{*}{$\begin{array}{l}\mathrm{IV} / \\
\mu \mathrm{L}\end{array}$} & \multirow[b]{2}{*}{$\begin{array}{c}\mathrm{CO} / \text { AutoS } / \\
{ }^{\circ} \mathrm{C}\end{array}$} & \multirow[b]{2}{*}{$\begin{array}{c}\text { Detector / } \\
\mathrm{nm}\end{array}$} & \multirow[b]{2}{*}{ Sample solution } & \multirow[b]{2}{*}{ Requirements } \\
\hline & & time / min & $\begin{array}{c}\text { Mobile } \\
\text { phase A / } \\
\%\end{array}$ & & & & & & & \\
\hline $\begin{array}{l}\text { Method } 5 \\
\text { optimized }\end{array}$ & $\begin{array}{c}\mathrm{A}: 0.01 \mathrm{M} \\
\mathrm{KH}_{2} \mathrm{PO}_{4} \mathrm{pH} 5.0 \\
\mathrm{~B}: \mathrm{MeCN} / \mathrm{MeOH} \\
96: 4 \mathrm{v} / \mathrm{v}\end{array}$ & $\begin{array}{c}0-2 \\
6 \\
14 \\
16 \\
26 \\
35 \\
35.1-40\end{array}$ & $\begin{array}{c}99.5 \\
98 \\
96 \\
88 \\
86 \\
75 \\
99.5\end{array}$ & $\begin{array}{c}\text { ACE C } 8 \\
150 \times 4.6 \mathrm{~mm} \text {, } \\
5 \mu \mathrm{m} \text { particle } \\
\text { size, } 100 \AA \text { pore } \\
\text { size, } 300 \mathrm{~m}^{2} \mathrm{~g}^{-1} \\
\text { superficial area, } \\
9 \% \text { carbon load }\end{array}$ & 1.0 & 10 & $40 / 4$ & 210 & $\begin{array}{l}0.5 \mathrm{mg} \mathrm{mL}^{-1} \mathrm{AMX} \\
\text { in mobile phase } \\
\mathrm{A} / \mathrm{MeOH} 8: 2 \mathrm{v} / \mathrm{v} \text {, } \\
\text { ultrasound for } \\
20 \text { min with ice to } \\
\text { keep temperature } \\
\text { below } 30^{\circ} \mathrm{C} \\
\text { (AMX is stable } \\
\text { for } 8 \mathrm{~h} \text { at } 25^{\circ} \mathrm{C} \text {, } \\
\text { for } 72 \mathrm{~h} \text { at } 4{ }^{\circ} \mathrm{C} \text {; } \\
\text { RS I, D1, and } \mathrm{P} \\
\text { for } 4 \mathrm{~h} \text { at both } \\
\text { temperatures) }\end{array}$ & $\begin{array}{c}\text { injector washing } \\
\text { solution: } 1.5 \mathrm{~mL} \\
\mathrm{MeCN} / \mathrm{H}_{2} \mathrm{O} \\
1: 1 \mathrm{v} / \mathrm{v} \text {, resolution } \\
\text { of each peak } \\
\text { NLT } 1, \text { AMX } \\
\text { theoretical plates } \\
\text { NLT } 6000, \text { AMX } \\
\text { asymmetry: } \\
0.8-1.0, \text { AMX } \\
\text { peak purity } \\
\text { NLT } 0.99\end{array}$ \\
\hline
\end{tabular}

Pharmacopoeial stability-indicating methods for AMX capsules

\begin{tabular}{|c|c|c|c|c|c|c|c|c|c|c|}
\hline British $^{19}$ & $\begin{array}{c}\text { A: } 0.05 \mathrm{M} \\
\mathrm{KH}_{2} \mathrm{PO}_{4} \mathrm{pH} 5 / \\
\mathrm{MeCN} 99: 1 \mathrm{v} / \mathrm{v} \\
\mathrm{B}: \text { buffer/MeCN } \\
80: 20 \mathrm{v} / \mathrm{v}\end{array}$ & $\begin{array}{c}0-\mathrm{AMX} \mathrm{t}_{\mathrm{R}} \\
25 \\
40 \\
40.1-55\end{array}$ & $\begin{array}{c}92 \\
0 \\
0 \\
92\end{array}$ & $\begin{array}{c}\text { Hypersil C18 } \\
250 \times 4.6 \mathrm{~mm}, \\
5 \mu \mathrm{m}, 120 \AA \text {, } \\
10 \% \text { carbon } \\
\text { load }\end{array}$ & 1 & 50 & rt & 254 & $\begin{array}{c}1.5 \mathrm{mg} \mathrm{mL}^{-1} \mathrm{AMX} \\
\text { in mobile phase } \mathrm{A} \text {, } \\
\text { shake for } 15 \mathrm{~min} \text {, } \\
\text { ultrasound for } \\
1 \mathrm{~min}\end{array}$ & $\begin{array}{l}\text { resolution between } \\
\text { internal standard } \\
\text { (cefadroxil) and } \\
\text { AMX NLT 2, } \\
\text { individual } \\
\text { impurities } \\
\text { NMT 1\% }\end{array}$ \\
\hline Japanese $^{20}$ & $\begin{array}{c}0.01 \mathrm{M} \\
\mathrm{CH}_{3} \mathrm{CO}_{2} \mathrm{Na} \mathrm{pH} \\
4.5 / \mathrm{MeOH} 95: 5 \\
\text { v/v }\end{array}$ & run time & $\min$ & $\begin{array}{c}\mathrm{C} 18300 \times \\
4.0 \mathrm{~mm}, 10 \mu \mathrm{m}\end{array}$ & $\begin{array}{l}\text { adjusted } \\
\text { for } \\
\mathrm{AMX} \mathrm{t}_{\mathrm{R}} \\
\text { in } 8 \mathrm{~min}\end{array}$ & 10 & $25 / \mathrm{rt}$ & 254 & $\begin{array}{c}2.0 \mathrm{mg} \mathrm{mL}^{-1} \mathrm{AMX} \\
\text { in } 0.08 \mathrm{mM} \text { boric } \\
\text { acid, shake for } \\
15 \mathrm{~min} \text {, centrifuge }\end{array}$ & $\begin{array}{l}\text { AMX theoretical } \\
\text { plates NLT } \\
2500, \text { symmetry } \\
\text { factor NMT } 1.5, \\
\text { individual } \\
\text { impurities } \\
\text { NMT } 1 \%\end{array}$ \\
\hline \multicolumn{11}{|c|}{ The most relevant stability-indicating method reported in literature for AMX capsules } \\
\hline Fong et $a l . .^{5}$ & $\begin{array}{c}\text { A: } 0.05 \mathrm{M} \\
\mathrm{KH}_{2} \mathrm{PO}_{4} \mathrm{pH} 5.9 \\
\mathrm{~B}: \mathrm{MeOH} / \mathrm{MeCN} \\
3: 1 \mathrm{v} / \mathrm{v}\end{array}$ & $\begin{array}{l}0-5 \\
25 \\
30 \\
35 \\
50\end{array}$ & $\begin{array}{c}100 \\
60 \\
60 \\
100 \\
100\end{array}$ & $\begin{array}{c}2 \text { Spherisorb } \\
\text { C18 columns } \\
\text { connected } \\
\text { in series: } \\
150 \times 4.6 \mathrm{~mm}, \\
5 \mu \mathrm{m}, 80 \AA \AA \\
11.5 \% \text { carbon } \\
\text { load }\end{array}$ & 1 & 50 & rt & 220 & $\begin{array}{l}1.0 \mathrm{mg} \mathrm{mL}^{-1} \\
\text { AMX in water, } \\
\text { ultrasound for } \\
30 \text { min with ice to } \\
\text { keep temperature } \\
\text { below } 30^{\circ} \mathrm{C} \\
\text { (stable for } 3 \mathrm{~h} \text { at } \\
\text { room temperature) }\end{array}$ & $\begin{array}{c}\mathrm{t}_{\mathrm{R}} \text { of RS D1/D2, } \\
\mathrm{I} \text { and A between } \\
1-12 \mathrm{~min}, \\
\text { RSD NMT } 15 \%\end{array}$ \\
\hline
\end{tabular}

IV: injection volume; CO: column oven temperature; AutoS: autosampler temperature; $\mathrm{MeOH}$ : methanol; MeCN: acetonitrile; AMX: amoxicillin; $\mathrm{t}_{\mathrm{R}}$ : retention time; RS: related substance; rt: room temperature; NLT: not less than; NMT: no more than; RSD: relative standard deviation.

degradation reaction in Dil1). It took approximately $1 \mathrm{~h}$ for AMX to completely dissolve. Related substance J was produced as a diluent artifact in a range of up to $6.0 \%$ in the reference solutions of AMX DS and DP, which was far beyond the MRL and the $0.17 \%$ determined by the manufacturer in the AMX DS, perhaps due to the increase in temperature in the ultrasound bath. Next, we tested solutions containing 10, 20 and 30\% methanol in $0.01 \mathrm{M} \mathrm{KH}_{2} \mathrm{PO}_{4}$ buffer $\mathrm{pH} 5$, controlling the temperature of the ultrasound bath through the occasional addition of ice to keep it below $30{ }^{\circ} \mathrm{C}$. The results were comparable to those reported by Felix et al., ${ }^{33}$ and the dissolution time decreased with increasing alcohol concentration. The greater the concentration of methanol, the greater the formation of amoxicilloic acid methyl ester (RS P), however, in a percentage range well below that observed for RS J using only buffer as the diluent. In the reference solutions prepared with buffer containing $20 \%$ methanol (named Dil2), the percentage area of RS P ranged from 0.13 to $0.25 \%$, while RS J ranged from 0.25 to $0.33 \%$. For this reason, the degradation reactions were carried out again using Dil2 under optimized conditions to obtain the desired degradation range (Table 3, degradation reaction in Dil2). All degraded samples showed percentage area for 

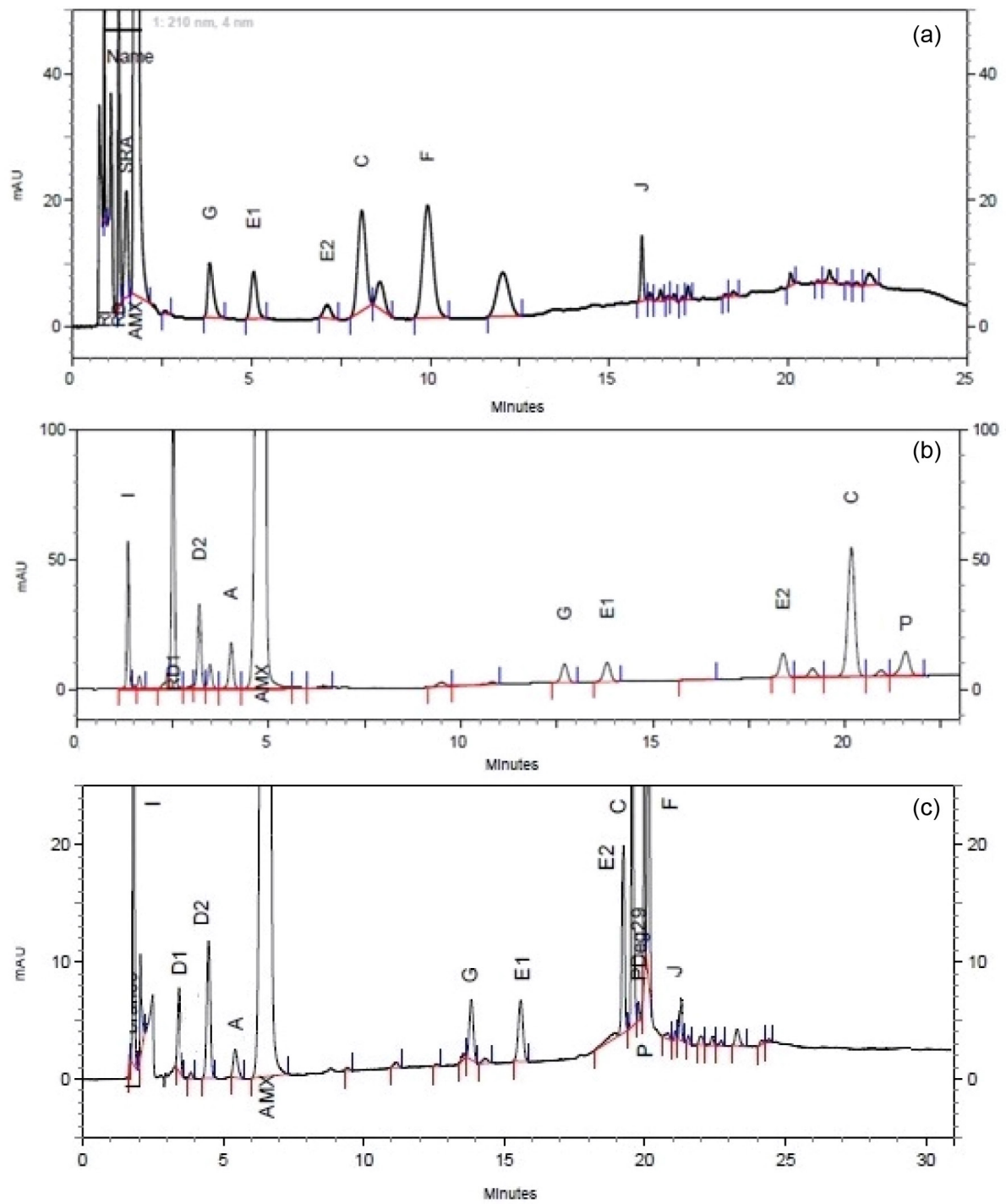

Figure 1. Chromatograms of the system suitability solution obtained using method 1 (a), method 2 (b), and method 5 (c). The system suitability solution contained the related substances I, D1, D2, A, G, E1, E2, C, F, J, P and amoxicillin (AMX).

RS P similar to the reference solutions, ranging from 0.05 to $0.25 \%$, except for samples degraded by copper(II), acid or alkali, which showed an average of 0.7, 4.3 and $35 \%$, respectively. The formation of RS J was observed in large proportion in the dry and wet thermodegraded samples (mean of 2.5 and $10 \%$, respectively), as expected, and much less in the copper catalyzed hydrolysis (1\%). All other degraded samples showed percentage areas $(0.04$ to $0.19 \%$ ) similar to the reference solutions. Considering all the pros and cons, $20 \%$ methanol in phosphate buffer $\mathrm{pH} 5$ was chosen as the best diluent as it reduced the AMX dissolution time for approximately $20 \mathrm{~min}$. In addition, the origin of RS P could be explained as coming exclusively from the diluent, while if there was an increase in the RS J, its origin could not be distinguished between diluent artifact or thermal degradation product, with a false increase in impurity that could disqualify the entire batch. About
80 PDegs were determined (Table S6, SI section) and mass balance was achieved (98.3-100.0\%) throughout the forced degradation study. Thermal degradation reactions displayed the release of a characteristic sulfur smell, which corroborates the carbonyl sulfide formation observed by Gálico et al..${ }^{34}$ using thermogravimetry coupled to Fourier transform infrared spectroscopy.

The placebo did not degrade under any of the conditions tested. AMX DS and DP showed similar degradation profiles (Figures 2 and 3), forming the largest number of PDegs during dry and wet thermal degradation (Table S6, SI section). However, the profiles obtained in the hydrolysis reactions were more dependent on the diluent used than on the concentration of the reagents or the method used. In Dil1, copper(II), alkali or acid catalyzed hydrolysis yielded RS D2 as the main degradation product, and in Dil2 it formed RS P, C and D2 (Figure 2). 
Table 3. Results of the forced degradation study of amoxicillin drug substance and drug product

\begin{tabular}{|c|c|c|}
\hline Degradation reaction (in diluent 1) & $\begin{array}{l}\text { Degraded } \\
\text { DS / \% }\end{array}$ & $\begin{array}{c}\text { Degraded } \\
\text { DP / \% }\end{array}$ \\
\hline $\mathrm{AH} 0.55 \mathrm{M} \mathrm{HCl}, 20 \mathrm{~min}, \mathrm{rt}$ & 22.6 & 16.4 \\
\hline $\mathrm{BH} 1.5 \mathrm{M} \mathrm{NaOH}, 15 \mathrm{~min}, \mathrm{rt}$ & 99.5 & 99.3 \\
\hline ВН $0.15 \mathrm{M} \mathrm{NaOH}, 30 \mathrm{~s}, \mathrm{rt}$ & 31.6 & 26.5 \\
\hline $\mathrm{Ox} 15 \% \mathrm{H}_{2} \mathrm{O}_{2}, 20 \mathrm{~min}, 60^{\circ} \mathrm{C}$ & 98.5 & $\mathrm{NC}$ \\
\hline $\mathrm{Ox} 15 \% \mathrm{H}_{2} \mathrm{O}_{2}, 20 \mathrm{~min}, \mathrm{rt}$ & 65.7 & $\mathrm{NC}$ \\
\hline $\mathrm{Ox} 1 \% \mathrm{H}_{2} \mathrm{O}_{2}, 10 \mathrm{~min}, \mathrm{rt}$ & 7.2 & $\mathrm{NC}$ \\
\hline Ox. $1 \% \mathrm{H}_{2} \mathrm{O}_{2}, 30 \mathrm{~min}, \mathrm{rt}$ & 15.8 & 15.4 \\
\hline DT $60{ }^{\circ} \mathrm{C}, 5 \mathrm{~h}$ & 0.0 & NP \\
\hline DT $105^{\circ} \mathrm{C}, 15 \mathrm{~h}$ & 45.8 & 25.3 \\
\hline DT $105^{\circ} \mathrm{C}, 1 \mathrm{~h}$ & 8.7 & 9.4 \\
\hline WT $105^{\circ} \mathrm{C}, 4.5 \mathrm{~h}$ & 36.0 & 34.7 \\
\hline $\mathrm{COP} 6 \mathrm{mM} \mathrm{Cu}(\mathrm{OAc})_{2}, 25 \mathrm{~min}, \mathrm{rt}$, buffer $\mathrm{pH} 7$ & 87.2 & NP \\
\hline $\mathrm{COP} 6 \mathrm{mM} \mathrm{Cu}(\mathrm{OAc})_{2}, 2 \mathrm{~min}, \mathrm{rt}$, buffer $\mathrm{pH} 7$ & 35.2 & NP \\
\hline COP $1 \mathrm{mM} \mathrm{Cu}(\mathrm{OAc})_{2}, 15 \mathrm{~min}$, rt, buffer $\mathrm{pH} 7$ & 16.3 & 13.5 \\
\hline \multicolumn{3}{|l|}{ Degradation reaction (in diluent 2) } \\
\hline AH $0.375 \mathrm{M} \mathrm{HCl}, 30 \mathrm{~min}, \mathrm{rt}$ & 15.8 & 14.1 \\
\hline BH 0.015 M NaOH, $15 \mathrm{~min}, \mathrm{rt}$ & 51.2 & 47.9 \\
\hline $\mathrm{Ox} 1 \% \mathrm{H}_{2} \mathrm{O}_{2}, 30 \mathrm{~min}, \mathrm{rt}$ & 12.1 & 12.6 \\
\hline DT $105^{\circ} \mathrm{C}, 3 \mathrm{~h}$ & 10.9 & 8.7 \\
\hline WT $105^{\circ} \mathrm{C}, 3 \mathrm{~h}$ & 27.8 & 22.3 \\
\hline $\begin{array}{l}\text { PhD } 1.2 \text { million lux h, } 200 \text { watts } \mathrm{h} \mathrm{m}^{-2}, 25^{\circ} \mathrm{C} \text {, } \\
17 \text { days }\end{array}$ & $\begin{array}{c}\text { DS: } 2.6 \\
\text { CAL: } 0.8\end{array}$ & $\begin{array}{c}\text { DP: } 3.8 \\
\text { CAL: } 1.6\end{array}$ \\
\hline$\underline{\mathrm{COP}} 1 \mathrm{mM} \mathrm{Cu}(\mathrm{OAc})_{2}, 30 \mathrm{~min}, \mathrm{rt}$, buffer $\mathrm{pH} 7$ & 21.7 & 21.9 \\
\hline
\end{tabular}

DS: amoxicillin trihydrate (AMX), drug substance; DP: amoxicillin $500 \mathrm{mg}$ capsule, drug product; $\mathrm{AH}$ : acidic hydrolysis; $\mathrm{BH}$ : alkaline hydrolysis; Ox: hydrogen peroxide oxidation; DT: dry thermodegradation; WT: wet thermodegradation; PhD: photodegradation; COP: reaction with copper(II) acetate; rt: room temperature; CAL: control for absence of light; NP: not performed; $\mathrm{Cu}(\mathrm{OAc})_{2}$ : copper II acetate. Diluent 1: $0.05 \mathrm{M}$ phosphate buffer $\mathrm{pH}$ 5. Diluent 2: $20 \%$ methanol in $0.01 \mathrm{M}$ phosphate buffer $\mathrm{pH} 5 \mathrm{v} / \mathrm{v}$. The $\mathrm{AH}, \mathrm{BH}, \mathrm{Ox}$ and $\mathrm{COP}$ reactions were carried out in amber flasks to avoid the influence of light. CAL was carried out in Petri plates wrapped in aluminum foil.

AMX DS, DP and placebo samples exposed to dry and wet heat and photodegradation were subjected to TG, DSC and XRPD analyses in order to investigate whether the extent of degradation was only chemical, or if there were any physical changes in AMX DS and DP. The DSC and TG curves of the reference DS agreed with those obtained by Gálico $e t a l .{ }^{34}$ The DSC profile of the reference DP was comparable to that of the reference DS and exhibited an endothermic event between 90 and $150{ }^{\circ} \mathrm{C}$ related to the dehydration of the molecule and, soon after, an exothermic event related to the degradation of AMX (Figure S3c, red and orange curves). The TG curve of the reference DP (Figure S4c, red and orange curves) showed a characteristic mass loss of $12.9 \%$ between 30 and $150{ }^{\circ} \mathrm{C}$ associated with dehydration of the molecule. The photodegraded samples showed no difference in the DSC and TG curves or in the XRPD patterns. However, the DS and DP thermodegraded samples showed profound changes in both curves (Figures S3 and S4, SI section), corroborating a total transformation of the DS crystal structure, resulting in the amorphization of DS, as revealed by the XRPD patterns (Figure S5b, SI section). Some authors argue that the amorphization of AMX occurs due to dehydration, ${ }^{35}$ while others claim that dehydrated AMX retains some crystallinity and reverts to trihydrate form upon absorbing water vapor, ${ }^{28}$ which could explain why the amorphous degraded DS samples lost a proportion of water similar to the reference samples (Figure S4, SI section). In contrast, the dry thermodegraded DP samples exhibited intact amoxicillin crystals interspersed with the amorphous form, perhaps partly protected by the excipient (Figure S5c, SI section, orange and green curves).

\section{SIM and assay method validation}

Carmo et al. ${ }^{36}$ reported the most common reasons for ANVISA to refuse licensing of DP, and many of them were linked to the development and validation of analytical methods. Due to this, all validation steps were followed according to ANVISA guidelines, ${ }^{22,23}$ considering linearity, range, selectivity, accuracy, precision, limit of quantitation (LOQ), limit of detection (LOD), and robustness.

\section{System suitability}

During the development of the method, the resolution between RSs A, D1/D2 and AMX, as well as between RSs $\mathrm{C}$ and $\mathrm{P}$, proved to be a critical point to indicate the good performance of the column and of the system in general. Furthermore, the use of methanol in the mobile phase and in the diluent may favor the appearance of RS P, a fact that must be verified when reporting RSs. Therefore, the system suitability (SS) should always be evaluated with the SS solution 2 and the SS solution 3 and/or 4 ("System suitability" sub-section, Figure S1, SI section), depending on whether the assay method or the SIM was applied, respectively, before the injection of the DP sample.

\section{Selectivity and specificity}

The maximum peak purity value (1.0) obtained for AMX and its various PDegs via photodiode array in all degradation reactions proved that the method was able to resolve the PDegs and AMX very well (Table S6, SI section). In addition, no peak overlap was observed in the diluent or placebo chromatograms on AMX retention time.

\section{Linearity and range}

Calibration curves were constructed by plotting the peak area against the concentration. Data were analyzed using 

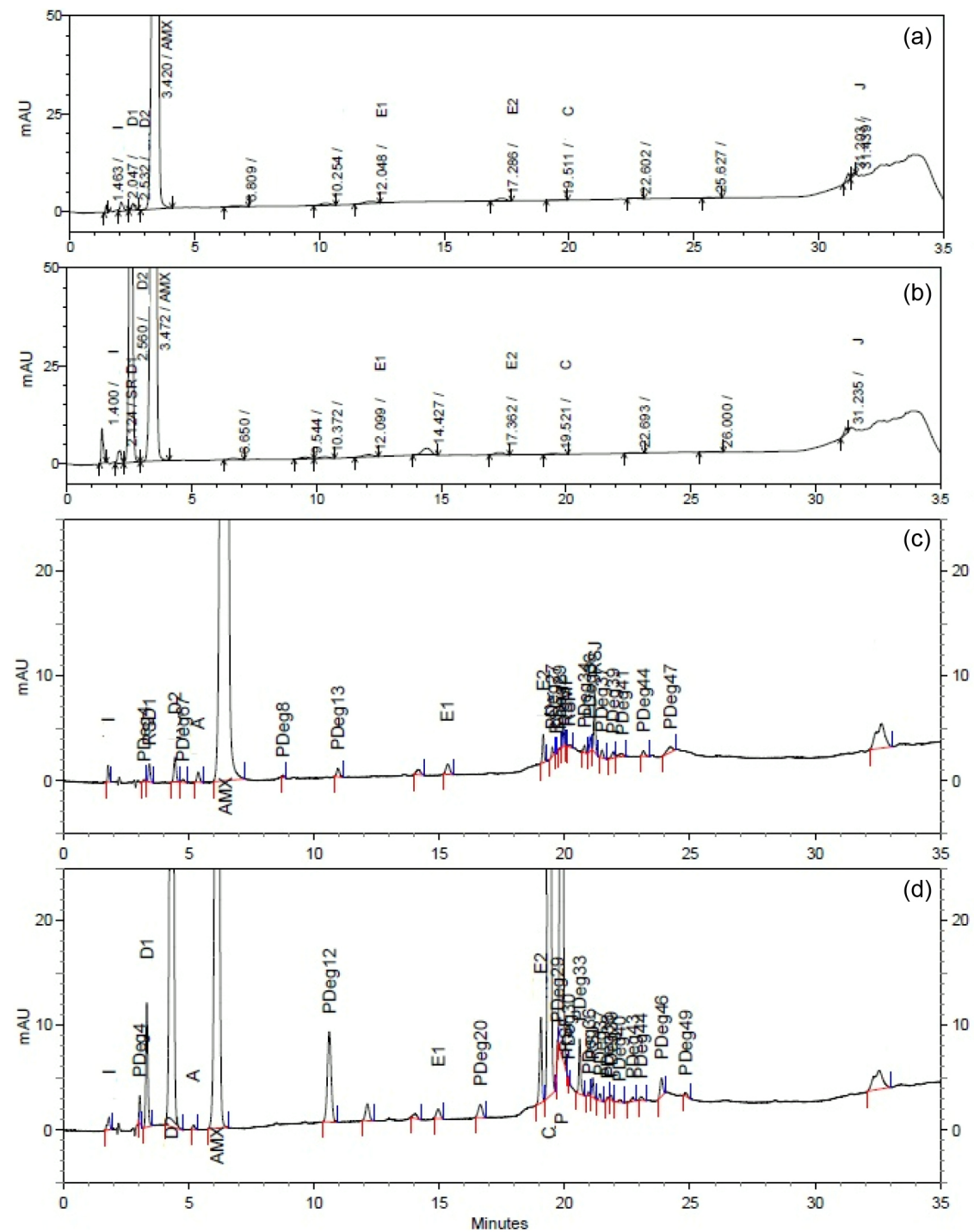

Figure 2. Alkaline hydrolysis chromatograms of the DS using diluent 1 obtained by method 3 ((a) reference DS; (b) degraded DS at $0.15 \mathrm{M} \mathrm{NaOH}, 30 \mathrm{~s}$ ), and using diluent 2 obtained by method 5 ((c) reference DS; (d) degraded DS at $0.015 \mathrm{M} \mathrm{NaOH}, 15 \mathrm{~min}$ ).

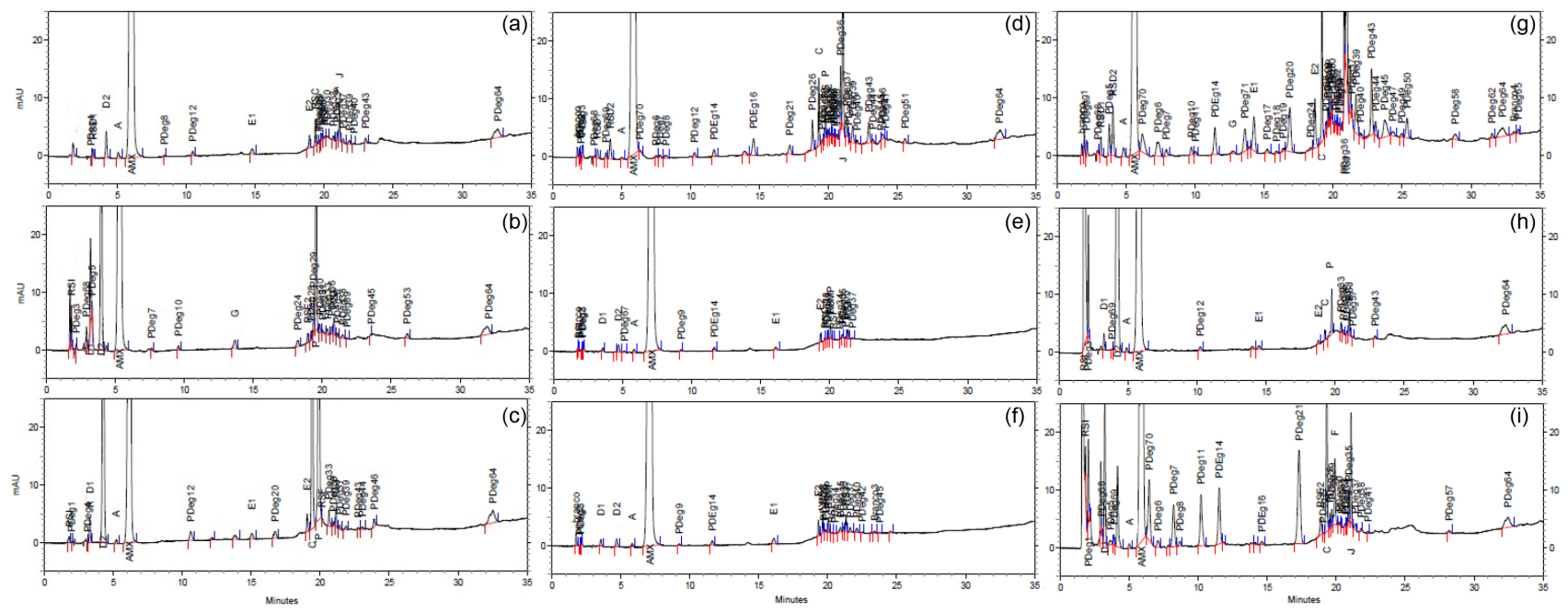

Figure 3. Chromatograms of the drug product (DP) forced degradation study using diluent 2 obtained by method 5 ((a) reference DP; (b) acidic hydrolysis; (c) alkaline hydrolysis; (d) thermal degradation (dry heat); (e) photodegradation; (f) control of absence of light for photodegradation; (g) thermal degradation (wet heat); (h) hydrogen peroxide oxidation; (i) reaction with copper(II) acetate). 
least squares linear regression. The values obtained for the coefficient of determination $\left(\mathrm{R}^{2}\right)$ in both curves (Figure 4 ) and the results of the statistical analyses (Table S3, SI section) showed a strong linear relationship between the variables $x$ (concentration) and $y$ (area) and homogeneity of variance of experimental errors for different observations.

\section{Limit of detection and limit of quantitation}

Initially, the LOD and LOQ were determined based on the intercept and slope values of the SIM curve as 0.139 and $0.417 \mu \mathrm{g} \mathrm{mL}{ }^{-1}$, respectively. ${ }^{24}$ Solutions with different concentrations were prepared and injected to obtain the empirical values (SI section, "Determination of limit of detection (LOD) and limit of quantitation (LOQ)" subsection) determined as $0.1 \mu \mathrm{g} \mathrm{mL}^{-1}$ (coefficient of variation $(\mathrm{CV})=2.5 \%)$ for LOD, and $0.3 \mu \mathrm{g} \mathrm{mL}^{-1}(\mathrm{CV}=2.7 \%)$ and accuracy of $100.4 \%$ for LOQ.

Determination of relative response factor (RRF) and relative retention time $\left(R t_{R}\right)$

RRF of AMX related substances A (0.525), G (0.336), $\mathrm{C}(0.1246)$ and $\mathrm{F}(1.461)$ were determined as described in the SI section ("Determination of relative response factor (RRF) of related substances" sub-section), and the RRF of any other related substances was considered equal to one. $\mathrm{Rt}_{\mathrm{R}}$ was calculated as the ratio between the respective measurement for each RS and AMX (SI section, "Determination of relative retention time $\left(\mathrm{Rt}_{\mathrm{R}}\right)$ of related substances" sub-section).

\section{Precision (intra- and inter-day) and accuracy}

Both the assay method and the SIM showed satisfactory precision and accuracy considering the analyses of the curve performed in solvent or the negligible matrix effect displayed (Table S4, SI section).
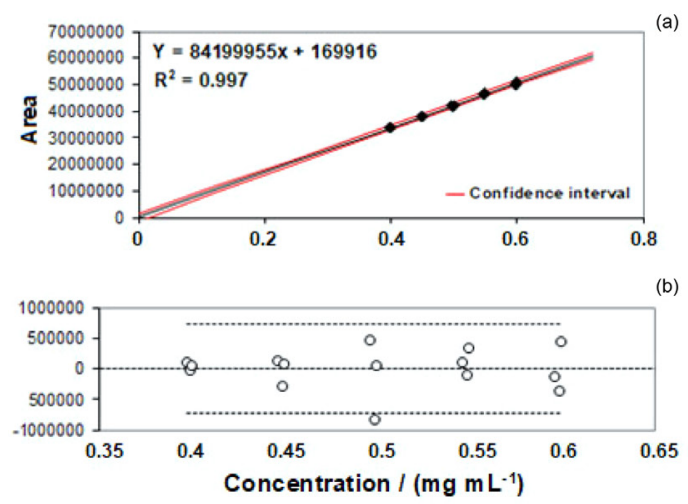

\section{Robustness}

Throughout the development of the method, it became evident that small changes in the chemical composition of the mobile phase, $\mathrm{pH}$, or flow would enormously influence the method resolution, causing peak displacement or overlapping due to the large number of PDegs and the zwitterionic nature of AMX, making it difficult even to identify the peaks through $\mathrm{Rt}_{\mathrm{R}}$. Therefore, these parameters must be kept constant. Only the variation in column oven temperature $\left(40 \pm 2{ }^{\circ} \mathrm{C}\right)$ did not significantly affect the precision and accuracy of the method (Table S5, SI section).

Filtering samples with nylon or regenerated cellulose membranes with a pore size of $0.45 \mu \mathrm{m}$ did not alter the chromatographic responses of AMX DS and DP or RSs (SI section, "Determination of influence of filtration" sub-section).

The solution stability study (SI section, "Determination of stability of solutions" sub-section) revealed that AMX DS and DP solutions in Dil2 remained stable for about $8 \mathrm{~h}$ at $25^{\circ} \mathrm{C}$ and for $72 \mathrm{~h}$ at $4{ }^{\circ} \mathrm{C}$. However, RS I, D1 and P lasted approximately $4 \mathrm{~h}$ at both temperatures, with degradation increasing over time due to hydrolysis. For this reason, once the solutions are prepared, analysis should not last any longer.

\section{Challenging of the SIM}

A DP sample from long-term stability study at the six-month stage was used to challenge the SIM. The chromatographic profile showed about 30 peaks (SI section, Table S7 and Figure S2), which were also observed in the 45\% thermodegraded DS sample (Table S6, SI section), corroborating the importance of this research in the prediction of PDegs and the efficiency of the method in fulfilling the purpose for which it was developed.
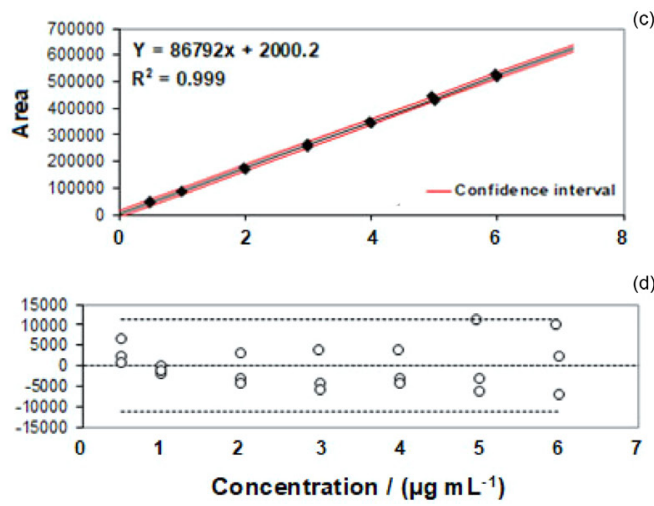

Figure 4. Calibration curves and residual plots from the assay (a, b) and from the stability-indicating method (c, d). 


\section{Conclusions}

The degradation profile showed that AMX was prone to all reactions, but mainly to thermal degradation and hydrolysis. For this reason, there must be deliberate control of heat and humidity throughout the manufacturing, transport and storage process of the AMX DS and DP. The increase in the amount of amorphous AMX observed in thermodegraded DP samples makes the product more susceptible to hydrolysis,${ }^{37}$ in addition to altering its bioavailability.

Amoxicillin DS and DP were susceptible to copper(II) and practically non-reactive to light (Figures $3 \mathrm{i}$ and $3 \mathrm{e}$, respectively), but some related substances had their content decreased during photodegradation, requiring a careful choice of packaging, which should be light-proof and free of transition metals.

The presence of RS D1/D2 as one of the PDegs resulting from the reaction between AMX and copper(II) indicates that copper plays a catalyst role in the hydrolysis of the $\beta$-lactam ring, corroborating the results reported by Chen et $a l .{ }^{38}$ However, RS C was the PDeg formed in the largest amount (Figure 3i), which points to a free radical-mediated auto-oxidation of AMX, in which there is an intramolecular attack on the $\beta$-lactam ring by the amino group in the benzyl position, with copper acting as an electron donor for molecular oxygen. ${ }^{39}$ This hypothesis could explain why the reaction extended for $24 \mathrm{~h}$, even with the addition of $0.1 \mathrm{M}$ EDTA as a reaction quencher, and the rate of degradation of AMX increased to $80 \%$. The occurrence of similar parallel mechanisms could also explain the contradictory results found in the literature on the degradation rates of AMX, in addition to the influence of the diluent and the concentration of AMX in the reaction.

In a forced degradation study, the percentage degradation range of $10-30 \%$, suggested in the literature, ${ }^{40}$ is not always sufficient to reveal all possible PDegs that may occur during a stability study. In the case of AMX, only a sample of DS thermodegraded at $105^{\circ} \mathrm{C}$ for $15 \mathrm{~h}$ (Table S6, SI section), which presented a degradation rate of $45 \%$, formed suffice amount and number of PDegs whose peaks could be superimposed on the peaks detected in the sample submitted to the long-term stability study, highlighting the importance of obtaining higher degradation ranges than those recommended in reactions in which the drug is more susceptible.

Throughout the development of the SIM, we realized that there is no $100 \%$ optimal condition, so we chose the least degrading one for AMX. The use of methanol in the diluent, in addition to being cheaper and less toxic than acetonitrile, reduced the analysis time when compared to other methods, which represents savings in the quality control laboratory and in the final price of the product.

The validated SIM was able to selectively detect and quantify AMX and all impurities present in a DP sample submitted to a long-term stability study.

\section{Supplementary Information}

Supplementary information (extra sections, tables and figures mentioned in the main text) is available free of charge at http://jbcs.sbq.org.br as PDF file.

\section{Acknowledgments}

The authors would like to thank Farmanguinhos, Manoel Miqueias Maia for his help in making the graphical abstract, and the reviewers for their excellent comments and suggestions, which made this work even better.

\section{Author Contributions}

Margareth B. C. Gallo, Diogo D. do Nascimento, Nelson M. Nunes, Juliana J. S. Medeiros, Janine Boniatti, Fabiana M. S. U. Monocorvo and Marcelo H. C. Chaves were responsible for conceptualization, methodology and data curation; Margareth B. C. Gallo for validation, investigation, visualization, writing original draft, reviewing and editing; José L. N. de Aguiar, Alessandra L. Esteves and Graça M. S. Guerra for project administration and funding; Flávia F. F. de Sousa and Luiz E. M. Ferreira for validation; Lucas G. I. Regis and Rafael Seiceira for investigation and data curation.

\section{References}

1. Deshpande, A. D.; Baheti, K. G.; Chatterjee, N. R.; Curr. Sci. 2004, 87, 1684.

2. de Marco, B. A.; Natori, J. S. H.; Fanelli, S.; Tótoli, E. G.; Salgado, H. R. N.; Crit. Rev. Anal. Chem. 2017, 47, 267.

3. Hsu, M.; Hsu, P.; Antimicrob. Agents Chemother. 1992, 36, 1276.

4. Lee, T. L.; D’Arconte, L.; Brooks, M. A.; J. Pharm. Sci. 1979, $68,454$.

5. Fong, G. W. K.; Martin, D. T.; Johnson, R. N.; Kho, B. T.; J. Chromatogr. 1984, 298, 459.

6. Nägele, E.; Moritz, R.; J. Am. Soc. Mass Spectrom. 2005, 16, 1670.

7. Pérez-Parada, A.; Agüiera, A.; Gomez-Ramos, M. M.; GarcıReyes, J. F.; Heinzen, H.; Fernandez-Alba, A. R.; Rapid Commun. Mass Spectrom. 2011, 25, 731.

8. Trovó, A. G.; Nogueira, R. F. P.; Agüera, A.; Fernandez-Alba, A. R.; Water Res. 2011, 45, 1394. 
9. Gozlan, I.; Rotstein, A.; Avisar, D.; Chemosphere 2013, 91, 985.

10. Atici, E. B.; Yazar, Y.; Ağtaş, Ç.; Ridvanoğlu, N.; Karlığa, B.; J. Pharm. Biomed. Anal. 2017, 136, 1.

11. Susanowo, H. J.: Forced Degradation Studies - Comparison Between ICH, EMA, FDA and WHO Guidelines and ANVISA's Resolution RDC 53/2015; MSc Dissertation, University of Bonn, Germany, 2016, available at https://dgra.de/media/pdf/ studium/masterthesis/master_janzen_h.pdfa, accessed in July 2021.

12. Raju, B. V. N.; Sharma, H. K.; Rao, S.; Rao, G. N.; Acta Chromatogr. 2009, 21, 57.

13. Tippa, D. M. R.; Singh, N.; Am. J. Anal. Chem. 2010, 1, 95.

14. Beg, S.; Hasnain, M. S.; Swain, S.; Kohli, K.; Int. J. Pharm. Sci. Nanotechnol. 2011, 4, 1423.

15. Frański, R.; Czerniel, J.; Kowalsk, M.; Frańska, M.; Rapid Commun. Mass Spectrom. 2014, 28, 713.

16. Konari, S. N.; Jacob, J. T.; J. Taibah Univ. Sci. 2015, 9, 167.

17. Batrawi, N.; Wahdan, S.; Al-Rimawi, F.; Sci. Pharm. 2017, 85, 6.

18. The European Pharmacopoeia, $10^{\text {th }}$ ed., Council of Europe/ European Directorate for the Quality of Medicines and Healthcare (EDQM): London, 2018.

19. The British Pharmacopoeia, The British Pharmacopoeia Comission Secretariat of the Medicines and Healthcare Products (MHRA): London, 2018.

20. The Japanese Pharmacopoeia, $17^{\text {th }}$ ed., Pharmaceutical and Medical Devices Agency (PMDA): Tokyo, 2016.

21. Alemzadeh, I.; Borghei, G.; Vafi, L.; Roostaazad, R.; Sci. Iran., Trans. C 2010, 17, 106.

22. Agência Nacional de Vigilância Sanitária (ANVISA); Resolução da Diretoria Colegiada (RDC) No. 166, de 24 de julho de 2017, Dispõe sobre A Validação de Métodos Analíticos e dá Outras Providências, 2017, Diário Oficial da União (DOU), Brasília, No. 141, de 25/07/2017, p. 87, available at https://www. in.gov.br/materia/-/asset_publisher/Kujrw0TZC2Mb/content/ id/19194581/do1-2017-07-25-resolucao-rdc-n-166-de-24-dejulho-de-2017-19194412, accessed in July 2021.

23. Agência Nacional de Vigilância Sanitária (ANVISA); Guia para Tratamento Estatístico da Validação Analítica, Guia No. 10, 2017, available at https://www.farmaceuticas.com.br/wpcontent/uploads/2017/09/Guia-10-v1-Tratamento-estatisticovalidacao-analitica.pdf, accessed in July 2021.

24. Bazílio, F. S.; Bomfim, M. V. J.; Almeida, R. J.; Abrantes, S. M. P.; Rev. Analytica 2012, 59, 60.

25. Cambridge Structural Database (CSD), https://www.ccdc.cam. ac.uk/structures/Search?Ccdcid=AMOXCT10\&DatabaseToSe arch=Published, accessed in July 2021.
26. Agência Nacional de Vigilância Sanitária (ANVISA); Resolução da Diretoria Colegiada (RDC) No. 53, Estabelece Parâmetros para a Notificação, Identificação e Qualificação de Produtos de Degradação em Medicamentos com Substâncias Ativas Sintéticas e Semissintéticas, Classificados como Novos, Genéricos e Similares, e Dá Outras Providências, 2015, Diário Oficial da União (DOU), Brasília, No. 234, de 08/12/2015, available at http://antigo.anvisa.gov.br/documents/10181/329 5768/\%281\%29RDC_53_2015_COMP.pdf/d38f507d-745c4f6b-a0a6-bd250f2e9892, accessed in July 2021.

27. Agência Nacional de Vigilância Sanitária (ANVISA); Guia para Obtenção do Perfil de Degradação, e Identificação e Qualificação de Produtos de Degradação em Medicamentos, Guia No. 04, 2015, https://storage.googleapis.com/wzukusers/user21948565/documents/b42ac29efc894ae08ab643c35a2cb2c1/ Guia\%2004\%20Perfil \%20e\%20produtos \%20de \% 20 degrada\%C3\%A7\%C3\%A3o\%20em\%20medicamentos.pdf, accessed in July 2021.

28. Bird, A. E. In Analytical Profiles of Drug Substances and Excipients, vol. 23, $1^{\text {st }}$ ed.; Brittain, H. G., ed.; Academic Press: London, UK, 1994.

29. Gensmantel, N. P.; Proctor, P.; Page, M. I.; J. Chem. Soc., Perkin Trans. 2 1980, 1725.

30. Frańska, M.; Ars Separatoria Acta 2012-2013, 9-10, 25.

31. Thambavita, D.; Galappatthy, P.; Mannapperuma, U.; Jayakody, L.; Cristofoletti, R.; Abrahamsson, B.; Groot, D. W.; Langguth, P.; Mehta, M.; Parr, A.; Polli, J. E.; Shah, V. P.; Dressman, J.; J. Pharm. Sci. 2017, 106, 2930.

32. The United States Pharmacopoeia, USP 41, The United States Pharmacopeial Convention: Rockville, 2018.

33. Felix, I. M. B.; Moreira, L. C.; Chiavone-Filho, O.; Mattedi, S.; Fluid Phase Equilib. 2016, 422, 78.

34. Gálico, D. A.; Guerra, R. B.; Legendre, A. O.; Schnitzler, E.; Mendes, R. A.; Bannach, G.; Braz. J. Therm. Anal. 2013, 2, 45.

35. Han, J.; Suryanarayanan, R.; Thermochim. Acta 1999, 329, 163.

36. Carmo, A. C. M.; Piras, S. S.; Rocha, N. F. M.; Gratieri, T.; BioMed Res. Int. 2017, ID 7894937.

37. Hickey, M. B.; Peterson, M. L.; Manas, E. S.; Alvarez, J.; Haeffner, F.; Almarsson, O.; J. Pharm. Sci. 2007, 96, 1090.

38. Chen, J.; Sun, P.; Zhou, X.; Zhang, Y.; Huang, C.-H.; Environ. Sci. Technol. 2015, 49, 4218.

39. Li, M.; Organic Chemistry of Drug Degradation; RSC Publishing: Cambridge, UK, 2012.

40. Pharmaceutical Stress Testing: Predicting Drug Degradation, $2^{\text {nd }}$ ed.; Baerstisch, S. W.; Alsante, K. M.; Reed, R. A., eds.; Taylor \& Francis: Boca Raton, USA, 2011.

Submitted: April 30, 2021

Published online: August 5, 2021 